\title{
Kinetics of particulate and solute marker passage in sheep supplemented with cationomycin and lasalocid antibiotics. Comparisons among methods for calculating mean retention time
}

\author{
L Gomez ${ }^{1 *}$, JP Lallès $2^{* *}, C$ Bogaërt ${ }^{3}$, C Poncet 4 \\ 1 'NRA, Unité de la Digestion Microbienne, Theix, 63122 Saint-Genès-Champanelle; \\ 2 INRA, Laboratoire du Jeune Ruminant, 65, rue de Saint-Brieuc, 35042 Rennes Cédex; \\ ${ }^{3}$ UCAAB, Service Scientifique, Chierry, 02402 Château-Thierry Cédex; \\ ${ }^{4}$ INRA, Unité de la Dynamique de la Digestion, Theix, 63122 Saint-Genè-Champanelle, France
}

(Received 11 March 1991; accepted 3 March 1992)

\begin{abstract}
Summary - Passage of particulate and solute markers in the digestive tract was studied in sheep fed a roughage-pelleted diet supplemented or not with ionophore antibiotics. Methods of marker administration (continuous infusion vs pulse-dose) and mathematical treatment of data were investigated. Antibiotic supplementation did not affect markers' mean retention time (MRT) significantly, regardless of sampling site, technique of marker administration or MRT calculation methods used. The pulse dose technique led to $20-30 \%$ higher estimate of particle markers $M R T$ in the entire gut and stomachs of sheep than did the continuous infusion method. Similar results were obtained between these methods for solute markers MRT at both sampling sites. Total MRT in the digestive tract could be partitioned among compartments using a deterministic model when applied to pulse-dose kinetics. Such a partitioning appeared uns:atisfactory with continuous-infusion data. Estimations of particle or solute markers $M R T$ in the rumen from duodenal and faecal marker kinetics were significantly different and rarely correlated.
\end{abstract}

antibiotic / marker / model / transit / sheep

Résumé - Cinétique du transit des marqueurs des particules et des liquides chez le mouton supplémenté en antibiotiques catiomycine et lasalocide. Comparaison entre les méthodes de calcul du temps moyen de rétention. Le transit des marqueurs des particules et des liquides dans le tube digestif a été étudié chez des moutons recevant une ration de fourrage compacté supplémentée ou non par des antibiotiques ionophores. Des méthodes d'administration des marqueurs (arrêt d'infusion continue vs dose unique) et de calcul du temps de séjour moyen (TSM) ont été comparées. La supplémentation en antibiotiques n'a pas significativement affecté le transit, quels que soient le marqueur, la méthode d'administration des marqueurs ou de calcul du TSM considérés. La

\footnotetext{
* Present address: INRA, Laboratoire des Groupes Sanguins, 78352 Jouy-en-Josas, Cedex, France

** Correspondence and reprints
} 
technique de dose unique a surestimé le TSM des marqueurs de particules de 20-30\% par rapport à l'arrêt d'infusion. Des résultats voisins entre ces techniques ont été obtenus pour les marqueurs des liquides. Le TSM total a pu être réparti en TSM compartimentaux par un modèle déterministe, dans le cas de le dose unique. Cette répartition est apparue peu satisfaisante pour l'arrêt d'infusion. Les estimations duodénale et fécale du TSM dans le rumen ont été significativement différentes et rarement corrélées.

antibiotlque / marqueur / modèle / mouton / transit

\section{INTRODUCTION}

The time feeds are retained in the digestive tract and particularly in the stomachs is an important factor of their digestion by ruminants (Evans, 1981a,b; Warner, 1981; Faichney, 1986). Feed efficiency can be improved through ration supplementation using ionophore antibiotics, an effect which may be explained mainly by a shift in digestion from rumen to intestines with or without apparent effects on digestibility of nutrients in the whole tract (Ricke et al, 1984; Darden et al, 1985; Spears, 1990). However, the mean retention time (MRT) of particles and liquid in various parts of the gut does not always reflect such changes. For instance, monensin has been reported to increase solute and particulate markers MRT in the rumen (Lemenager et al, 1978; Allen and Harrison, 1979; Adams et al, 1981; Leng et al, 1984; Van Haecke et al, 1985; Ward et al, 1990a, b). However, nil or opposite effects have also been observed (Van Nevel and Demeyer, 1979; Delaney and Ellis, 1983; Arndt and Richardson, 1985; Faulkner et al, 1985), suggesting that antibiotic action may be more complex depending on the particular dietary situation.

The present results deal with the effect on MRT of less commonly employed ionophore antibiotics, cationomycin and lasalocid, which were used as feed additives in a study of digestion in sheep (Bogaërt et al, 1991; Gomez et al, 1991). Taking ad- vantage of this experiment, particulate and solute markers MRT measurements were also carried out simultaneously by: 1) terminating a continuous rumen infusion of markers; and 2) administering a pulse dose of markers into the rumen, and then in both situations following changes with time in the amount of marker excreted and/ or marker concentration in duodenal digesta and faeces according to Faichney (1975). Some aspects of mathematical treatment of marker concentration patterns were also considered using algebraic and modelling techniques. Comparisons between deterministic and stochastic models were not investigated in the present study, for the former have generally proved satisfactory (Quiroz et al, 1988), although small but systematic deviations from reference values have been reported (Faichney and Boston, 1983). A comprehensive comparison of models has also been published recently (Lallès et al, 1991).

\section{MATERIAL AND METHODS}

\section{Animals, diets and experimental design}

The animals, diets and experimental design were those used in a concurrent study of the effet of 2 ionophore antibiotics, cationomycin and lasalocid, on ruminal digestion (Bogaërt et al, 1991; Gomez et al, 1991). Briefly, 6 adult Texel sheep (average body weight $67 \mathrm{~kg}$ ) were fitted with rumen and duodenal simple cannulae. A 
pelleted, roughage-based diet (intake: $1060 \mathrm{~g}$ $\mathrm{DM} / \mathrm{d})$ supplemented (33 ppm) or not with antibiotics was fed in 8 equal meals/d to the sheep, as presented elsewhere (Bogaërt et al, 1991). While sheep were kept in metabolism cages, particulate and solute digesta markers, ytterbium (Yb) chloride and chromium (Cr)-EDTA respectively, were continuously and separately infused in the rumen at rates of $130 \mathrm{mg} \mathrm{Yb}$ and $140 \mathrm{mg} \mathrm{Cr} / \mathrm{d}$. Each experimental period was organized as follows: $21 \mathrm{~d}$ adaptation to diets with the last $5 \mathrm{~d}$ for adaptation to cages and infusion, $6 \mathrm{~d}$ digestibility and $2 \mathrm{~d}$ digesta flow trial. After sheep under continuous marker infusion had rested from digesta collection for $3 \mathrm{~d}$, samples for MRT measurements were taken over $6 \mathrm{~d}$.

\section{Marker administration, duodenal digesta and faeces sampling}

At the beginning of MRT measurements, flow marker (Yb and $\mathrm{Cr}$-EDTA) infusion in the rumen was stopped (zero time) and the decline in marker concentration was followed in duodenal digesta and in faeces as described by Faichney (1975). At zero time, sheep were also dosed with a second set of markers, europium (Eu) and polyethylene glycol (PEG). The former, obtained as the chloride, had previously been attached to cell wall constituents of a fraction of the experimental feed according to a competitive binding procedure (Ellis and Beever, 1984). Sodium citrate was used as the ligand and immersion took place at $\mathrm{pH} 2.0$. Twenty-nine percent of the labelled particles were retained on a 1-mm screen by wet sieving, the remainder being entirely recovered on the $0.8-0.16 \mathrm{~mm}$ sieves. The resulting mean particle size calculated as the screen size of the sieve on which half of particles in weight would be collected was 0.9 $\mathrm{mm}$. A dose of $30 \mathrm{~g}$ DM oven-dried labelled feed (5 $\mathrm{mg} \mathrm{Eu} / \mathrm{g} \mathrm{DM}$ ) was offered to the sheep at the beginning of a meal. At the same time, $10 \mathrm{~g}$ $P E G$ in $50 \mathrm{ml}$ of water was given into the rumen through the cannula.

Duodenal digesta were collected manually every $2 \mathrm{~h}$ for the first $12 \mathrm{~h}$, every $5 \mathrm{~h}$ fr $3 \mathrm{~m} 13$ to $42 \mathrm{~h}$ and then at $7 \mathrm{~h}$ intervals from 43 to $84 \mathrm{~h}$ post-dosing. Faeces were collected automatically every $3 \mathrm{~h}$ between 6 and $36 \mathrm{~h}$, every $6 \mathrm{~h}$ from 37 to $72 \mathrm{~h}$ and then at $12 \mathrm{~h}$ intervals from 73 to $144 \mathrm{~h}$ post-dosing. Subsamples were prepared after homogenization of duodenal digesta and faeces, and frozen $\left(-20^{\circ} \mathrm{C}\right)$ until analysed.

\section{Marker analysis}

The markers $\mathrm{Yb}, \mathrm{Cr}$ and Eu were assayed after freeze-dried digesta samples had been ashed at $550^{\circ} \mathrm{C}$ for $5 \mathrm{~h}$. Markers were extracted from ash in a hot sulfuric/phosphoric acid solution as described for $\mathrm{Cr}$ by Siddons et al (1985) and then modified for simultaneous extraction of $\mathrm{Cr}$ and Yb by Lallès and Poncet (1990a). They were assayed using atomic absorption spectrophotometry (Perkin-Elmer 2380) in a nitrous oxide/ acetylene flame for $\mathrm{Yb}$ (wavelength $(\tau)=398.8$ $\mathrm{nm})$ and $\mathrm{Eu}(\tau=459.4 \mathrm{~nm})$, and in an air/ acetylene flame for $\mathrm{Cr}(\tau=357.9 \mathrm{~nm})$, following manufacturer's recommendations. Blank samples of digesta and faeces were used to prepare respective standards in a similar way.

PEG was assayed in the liquid phase of undiluted digesta and aqueous extract $(5 / 1 \mathrm{v} / \mathrm{v})$ of thawed faeces by turbidimetry according to $\mathrm{Hy}$ dén (1955) as modified by Malawer and Powell (1967).

\section{MRT estimation and statistical analysis}

The MRT of particulate (Eu) and solute (PEG) markers given as a single dose were calculated using numerical (algebraic) integration (eq [8] of Faichney, 1975) applied to faecal data (table I). However, this method of reference could not be applied to duodenal marker patterns as total digesta flow cannot be measured directly using simple cannulae (Faichney, 1975). The "method of the moments" considered to be an approximation of markers MRT (Thielemans et al, 1978; table I) was applied to faecal and duodenal data. At the latter sampling site, this equation was preferred to that (eq [9]) proposed by Faichney (1975) since digesta sampling took place at irregular (increasing) time intervals. In oder to provide a more thorough comparison of MRT calculation methods, faecal and duodenal marker patterns were then fitted to the most commonly used deterministic model of Grovum and Williams (1973). Following administration of a pulse dose of mark$\mathrm{er}$, changes in concentration over time at a given sampling site are related to initial marker concen- 


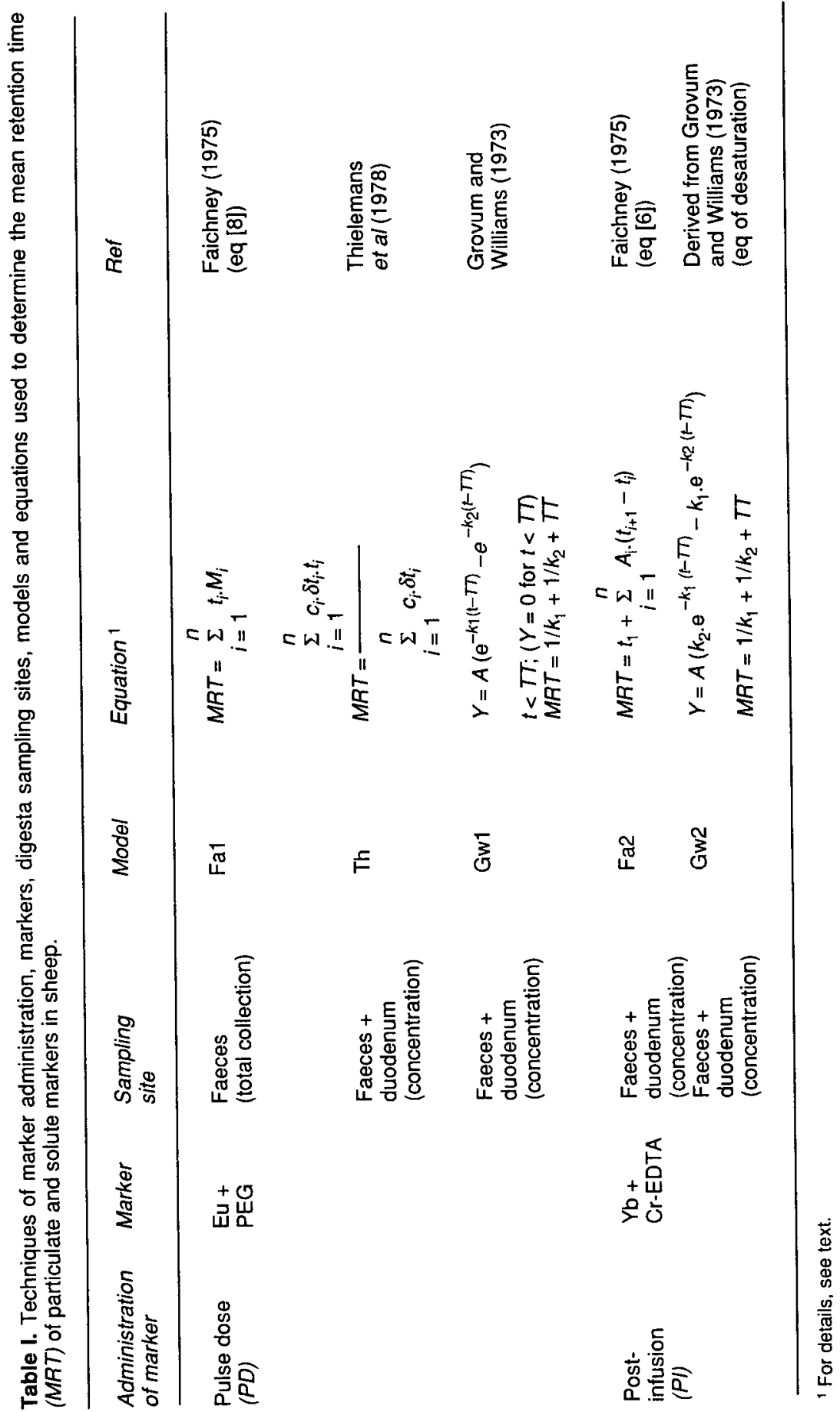


tration in the first pool assuming instantaneous mixing, turnover rates $\left(k_{1}\right.$ and $\left.k_{2}\right)$ in mixing compartments and a time delay $(T T)$ before marker appearance at the duodenum or in faeces.

Similarly, the MRT of particulate $(\mathrm{Yb})$ and solute (Cr-EDTA) markers administered by continuous rumen infusion was first calculated using numerical integration (eq [6] of Faichney, 1975; table I) applied to faecal and duodenal marker concentration patterns. The MAT of markers was also calculated at both sites using an equation (table I; last eq) derived from that of Grovum and Williams (1973) to describe the "desaturation" curve of a marker administered in a 2mixing compartment plus time delay system. In other words, it would represent the amount of marker remaining in the system at time $t$.

Respective models were fitted to individual sets of marker concentration data at duodenal and faecal sites using a computer programme for non-linear regression analysis (Snedecor and Cochran, 1971) based on a Marquardt least-square iteration procedure. Fits were considered to be satisfactory when 2-3 successive sets of different initial parameters led to very close parameter estimates. Final results retained were those which provided lowest overall residual standard errors and lowest standard deviations on each estimated parameter (coefficient of variation below 5-10\%). Data were treated by analysis of variance according to the statistical model of 2 Latin inverse squares (Gill, 1978) as described by Bogaërt et al (1991). As antibiotics were shown to have no significant $(P$ $\geq 0.05$ ) effect on digesta markers MRT (see Results), data were pooled across treatments and comparisons between marker administration techniques and among MRT calculation methods were carried out using Student paired t-test and linear regression analysis (Snedecor and Cochran, 1971).

\section{RESULTS}

For reasons of clarity, results dealing with: 1) antibiotic effects on marker retention, and 2) comparisons among marker and MRT methods have been presented separately.

\section{lonophore antibiotics and transit of particulate and solute digesta markers}

Results are presented in table II. Addition of cationomycin or lasalocid to the basal diet had no significant effect $(P \geq 0.05)$ on particulate and solute digesta markers $M R T$ in the entire gut and stomachs of sheep regardless of marker administration procedure and MRT calculation methods used. Considering the algebraic methods, MRT of particle and solute markers in the whole tract was 55 and $39 \mathrm{~h}$ respectively. Approximately half of this time was spent in the stomachs (27 and $17 \mathrm{~h}$ respectively) leading to fairly close absolute MRT values ( 28 vs $22 \mathrm{~h}$ ) in the post-stomach sections of the gut. Differences between marker administration techniques and among $M R T$ calculation methods were nevertheless apparent from results in table II. They are detailed in the following section.

\section{Marker administration techniques and MRT calculation methods}

\section{Quality of data fitting using models}

Both models led to a better fit of faecal than duodenal marker kinetics (table III). This may be attributed mainly to the generally accepted observation that when sampling duodenal digesta, the delay of marker appearance or concentration decrease is rather short, the number of data points is limited in the first part of curves whatever their shape, and changes in marker concentration are rather large shortly after zero time. This latter problem may be related to marker heterogeneity within the rumen soon after dosing and/or sampling bias through the duodenal cannula. Considering the method of marker administration/modelling, 
Table II. Influence of antibiotic supplementation on MRT of particulate and solute markers in the whole digestive tract, the stomachs and subcompartments in sheep.

\begin{tabular}{|c|c|c|c|c|c|c|c|c|}
\hline \multirow{2}{*}{$\begin{array}{l}\text { Sampling } \\
\text { site }\end{array}$} & \multirow{2}{*}{$\begin{array}{c}\text { Administration } \\
/ \text { marker }^{2}\end{array}$} & \multirow{2}{*}{ Model $^{3}$} & \multirow{2}{*}{$\begin{array}{c}\text { Transit } \\
\text { parameter } 4\end{array}$} & \multicolumn{3}{|c|}{ Treatment ${ }^{1}$} & \multirow[t]{2}{*}{ SEM } & \multirow[t]{2}{*}{ Effect ${ }^{5}$} \\
\hline & & & & $c$ & $L$ & $\mathrm{Ca}$ & & \\
\hline \multirow[t]{4}{*}{ Faeces } & $P D /$ Eu & $\begin{array}{l}\text { Fa1 } \\
\text { Th }\end{array}$ & $\begin{array}{l}\text { MRTC1 } \\
T T \\
M R T C 2 \\
M R T W T \\
M R T W T \\
M R T W T\end{array}$ & $\begin{array}{l}25.9 \\
19.0 \\
13.3 \\
58.1 \\
53.8 \\
54.0\end{array}$ & $\begin{array}{l}27.2 \\
19.0 \\
15.4 \\
61.6 \\
56.4 \\
56.6\end{array}$ & $\begin{array}{l}25.5 \\
18.0 \\
15.4 \\
58.9 \\
53.8 \\
53.8\end{array}$ & $\begin{array}{l}1.9 \\
2.6 \\
2.0 \\
1.9 \\
1.9 \\
1.8\end{array}$ & $\begin{array}{l}\text { NS } \\
\text { NS } \\
\text { NS } \\
\text { NS } \\
\text { NS } \\
\text { NS }\end{array}$ \\
\hline & $P I / Y b$ & Gw2 & $\begin{array}{l}\text { MRTC1 } \\
T T \\
M R T C 2 \\
M R T W T \\
M R T W T\end{array}$ & $\begin{array}{r}25.5 \\
20.9 \\
0.1 \\
46.5 \\
45.9\end{array}$ & \begin{tabular}{r|}
24.6 \\
22.0 \\
0.1 \\
46.7 \\
45.5
\end{tabular} & \begin{tabular}{r|r|}
23.3 & \\
21.2 & \\
0.1 & 44.5 \\
43.5 &
\end{tabular} & $\begin{array}{l}2.2 \\
2.8 \\
0.1 \\
3.6 \\
3.6\end{array}$ & $\begin{array}{l}\text { NS } \\
\text { NS } \\
\text { NS } \\
\text { NS } \\
\text { NS }\end{array}$ \\
\hline & PD/PEG & $\begin{array}{l}\text { Fa1 } \\
\text { Th }\end{array}$ & $\begin{array}{l}\text { MRTC1 } \\
T T \\
\text { MRTC2 } \\
M R T W T \\
M R T W T \\
\text { MRTWT }\end{array}$ & \begin{tabular}{r|}
15.9 \\
16.6 \\
8.9 \\
41.3 \\
38.9 \\
39.1
\end{tabular} & \begin{tabular}{r|}
17.0 \\
17.4 \\
8.2 \\
42.5 \\
40.1 \\
40.2
\end{tabular} & \begin{tabular}{r|}
16.9 \\
17.2 \\
9.1 \\
41.3 \\
37.8 \\
37.6
\end{tabular} & $\begin{array}{l}2.2 \\
1.1 \\
1.1 \\
2.5 \\
2.0 \\
2.0\end{array}$ & $\begin{array}{l}\text { NS } \\
\text { NS } \\
\text { NS } \\
\text { NS } \\
\text { NS } \\
\text { NS }\end{array}$ \\
\hline & $P / / \mathrm{Cr}$-EDTA & A Gw2 & $\begin{array}{l}\text { MRTC1 } \\
T T \\
M R T C 2 \\
M R T W T \\
M R T W T\end{array}$ & $\begin{array}{r}21.9 \\
18.5 \\
0.8 \\
41.8 \\
40.6\end{array}$ & \begin{tabular}{r|r}
23.6 \\
18.6 \\
0.4 \\
42.4 \\
39.6
\end{tabular} & \begin{tabular}{r|}
22.9 \\
16.4 \\
0.1 \\
39.4 \\
38.4
\end{tabular} & $\begin{array}{l}2.6 \\
1.3 \\
0.0 \\
3.4 \\
3.4\end{array}$ & $\begin{array}{l}\text { NS } \\
\text { NS } \\
\text { NS } \\
\text { NS } \\
\text { NS }\end{array}$ \\
\hline \multirow[t]{4}{*}{ Duodenum } & $P D /$ Eu & Gw1 & $\begin{array}{l}\text { MRTC1 } \\
T T \\
M R T C 2 \\
M R T S T \\
M R T S T\end{array}$ & $\begin{array}{r}22.1 \\
1.8 \\
4.9 \\
30.0 \\
26.1\end{array}$ & $\begin{array}{r}23.1 \\
2.4 \\
6.2 \\
32.6 \\
27.5\end{array}$ & $\begin{array}{r}21.7 \\
2.4 \\
6.1 \\
33.4 \\
27.7\end{array}$ & $\begin{array}{l}2.1 \\
1.0 \\
2.4 \\
3.4 \\
1.7\end{array}$ & $\begin{array}{l}\text { NS } \\
\text { NS } \\
\text { NS } \\
\text { NS } \\
\text { NS }\end{array}$ \\
\hline & $P / / \mathrm{Yb}$ & Fa2 & $\begin{array}{l}\text { MRTC1 } \\
T T \\
\text { MRTC2 } \\
\text { MRTST } \\
\text { MRTST }\end{array}$ & $\begin{array}{r}21.5 \\
1.4 \\
0.6 \\
23.4 \\
25.1\end{array}$ & $\begin{array}{r}20.4 \\
1.2 \\
0.1 \\
21.7 \\
23.4\end{array}$ & $\begin{array}{r}20.0 \\
1.4 \\
0.4 \\
21.8 \\
22.1\end{array}$ & $\begin{array}{l}1.4 \\
1.2 \\
0.4 \\
1.3 \\
1.3\end{array}$ & $\begin{array}{l}\text { NS } \\
\text { NS } \\
\text { NS } \\
\text { NS } \\
\text { NS }\end{array}$ \\
\hline & $P D /$ PEG & Gw1 & $\begin{array}{l}\text { MRTC1 } \\
T T \\
M R T C 2 \\
M R T S T \\
M R T S T\end{array}$ & $\begin{array}{r}9.8 \\
0.2 \\
4.9 \\
14.5 \\
16.4\end{array}$ & $\begin{array}{r}9.1 \\
0.3 \\
6.2 \\
16.3 \\
18.3\end{array}$ & $\begin{array}{r}7.7 \\
0.2 \\
6.1 \\
12.8 \\
16.2\end{array}$ & $\begin{array}{l}2.4 \\
0.4 \\
2.4 \\
2.6 \\
1.3\end{array}$ & $\begin{array}{l}\text { NS } \\
\text { NS } \\
\text { NS } \\
\text { NS } \\
\text { NS }\end{array}$ \\
\hline & PI/Cr-EDTA & A Gw2 & $\begin{array}{l}\text { MRTC1 } \\
T T \\
\text { MRTC2 } \\
\text { MRTST } \\
\text { MRTST }\end{array}$ & $\begin{array}{r}14.6 \\
2.3 \\
0.0 \\
15.4 \\
15.9\end{array}$ & $\begin{array}{r}14.7 \\
1.4 \\
0.2 \\
16.2 \\
18.3\end{array}$ & $\begin{array}{r}12.2 \\
1.4 \\
0.3 \\
14.2 \\
17.9\end{array}$ & $\begin{array}{l}2.6 \\
0.9 \\
0.1 \\
2.2 \\
3.1\end{array}$ & $\begin{array}{l}\text { NS } \\
\text { NS } \\
\text { NS } \\
\text { NS } \\
\text { NS }\end{array}$ \\
\hline
\end{tabular}

\footnotetext{
${ }^{1} \mathrm{C}$, control; L, lasalocid; Ca, cationomycin; ${ }^{2,3,4}$ for details, see text and table I; ${ }^{5} \mathrm{NS}$, not significant $(P \geq 0.05)$.
} 
Table III. Quality of curve fitting using models applied to faecal and duodenal marker concentration kinetics.

\begin{tabular}{llll}
\hline \multirow{2}{*}{$\begin{array}{l}\text { Administration } \\
\text { /marker }\end{array}$} & Mode/ & \multicolumn{2}{c}{ Proportion of variance $(S D)^{1}$} \\
\cline { 3 - 4 } & & Faeces & Duodenum \\
\hline PD/Eu & Gw1 & $97.8(2.73)$ & $94.0(4.53)$ \\
$P I / Y b$ & Gw2 & $98.9(0.66)$ & $98.0(1.06)$ \\
PD/PEG & Gw1 & $96.2(2.47)$ & $89.5(8.59)$ Pl/Cr-EDTA \\
& Gw2 & $96.5(2.86)$ & $94.6(10.7)$ \\
\hline
\end{tabular}

1 Proportion of variance accounted for by models (\% total variance SD : standard deviation); ${ }^{2,}{ }^{3}$ for details, see text.

equation Gw2 tended to provide better fits than equation Gw1, as judged by respective proportions of variance accounted for by models (table III). However, these differences were not significant $(P \geq 0.05)$. The visual analysis of the distribution of residuals did not reveal any significant bias in data fits.

\section{MRT in the whole tract (MRTWT) and stomachs (MRTST)}

A comparison of the various methods is presented in table IV. MRTWT was estimated for the particulate marker Eu (55 h) given by pulse dose in a similar way $(P \geq$ $0.05)$ using both algebraic methods which were highly correlated $(r>0.98$; slope 0.98 ; intercept $<1 \mathrm{~h}$ ). The model Gw1 overestimated these values by $11 \%$ $(M R T=60 \mathrm{~h})$. In post-infusion situations, MRTWT calculated using Fa2 and Gw2 models was $15 \%$ lower than that obtained for Eu given as a single dose of labelled feed (45-46 vs 55-60 h). Differences between calculation methods were much lower for the solute markers and gene ally not significant $(P \geq 0.05)$, except for Gw1 and Gw2 $(P<0.05)$. They overestimated $M R T$ by $4-7 \%$ when compared with the respective reference methods of Faichney (1975).

At the duodenal level, modelling methods provided respectively higher (Gw1; $32.5 \mathrm{~h}$ ) and lower (Gw2; $22.3 \mathrm{~h}$ ) estimates of particulate markers MRT than the corresponding algebraic methods (Th $27.1 \mathrm{~h}$; Fa2 $23.5 \mathrm{~h}$ ). Correlations between calculation methods were high within- and low between marker administration techniques. An important bias $(P<0.01)$ was observed between Th and Gw1 methods, the latter underestimating $M R T$ at low values and overestimating it at high values. Similar conclusions can be drawn from table IV for solute markers $M R T$, although, in both cases of marker administration, modelling methods led to lower $(P<0.05)$ MRT estimates than those obtained by algebraic calculations; a significant bias $(P<0.01)$ was observed between Fa2 and Gw2.

\section{Partition of total tract and stomachs MRT into partial MRTs}

The 2-mixing-compartment-one-delay model of Grovum and Williams (1973) as fitted to pulse dose (Gw1) and post-infusion (Gw2) marker kinetics, was applied to all data sets and parameters related to MRT 


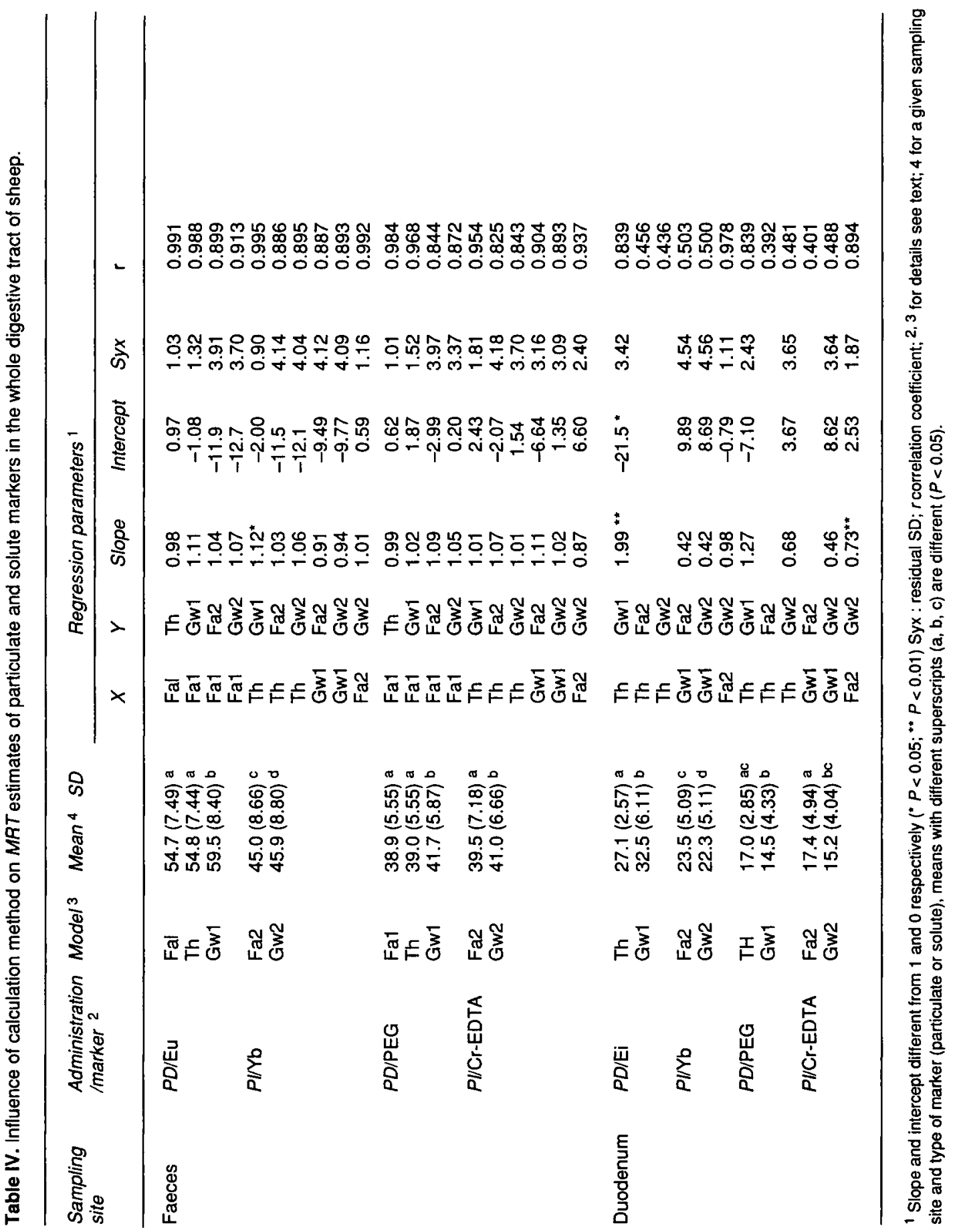




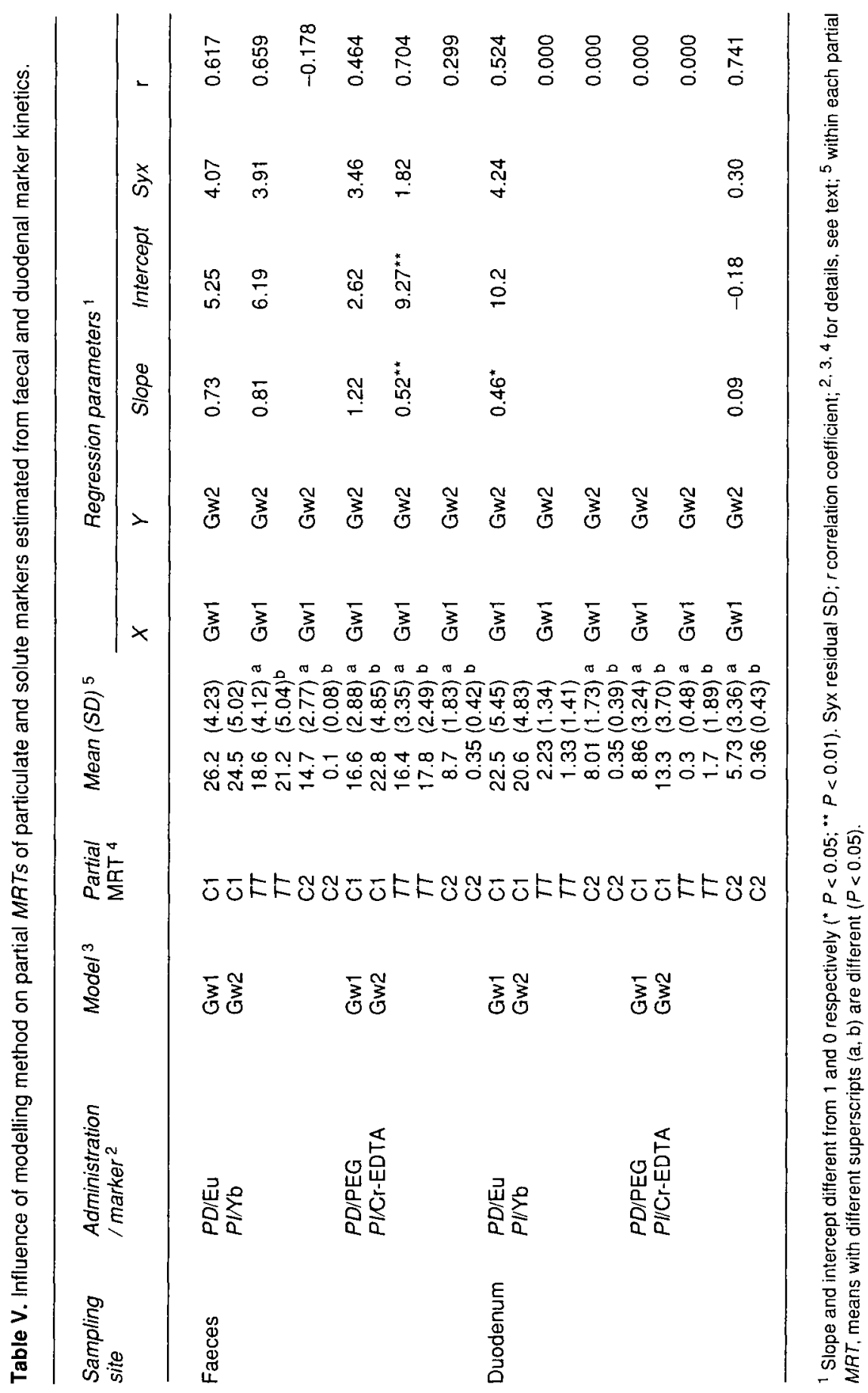


of markers in the compartments compared (table V). The most striking feature was that the latter model applied to kinetics obtained after cessation of marker infusion generated very low MRT attributed to compartment $\mathrm{C} 2$, regardless of sampling site and marker. For example, estimated retention of particulate markers from faecal data in the compartment $\mathrm{C} 2$ was 14.7 (Gw1) and $0.1 \mathrm{~h}$ (Gw2), probably representing problems of fit (see Discussion). The consequence was an increased $T T$ and/or $M R T$ in $\mathrm{C} 1$. At the faecal level, correlations between Gw1 and Gw2 models for $T T$ and $C_{1} M R T$ were moderate, suggesting that main parts of marker concentration curves partly described similar (integrated) phenomena. At the duodenum, differences between models were also apparent but values were generally not correlated $(P \geq 0.05)$.

\section{Influence of sampling site on estimation of MRT in mixing compartments}

This set of comparisons was intended as MRT of digesta markers in the rumen (supposed to be represented by $\mathrm{C} 1$ ) may be estimated from faecal curve modelling. Results in table VI show that MRT in the rumen was generally overestimated by $20-40 \%$ when faecal data were used. Furthermore, correlations were low and most often not significant ( $P \geq 0.05)$. Gw2 model was not considered here because of abnormally low $\mathrm{C} 2$ estimates.

\section{Identification of mixing compartments from faecal data analysis}

As suggested by Faichney and Boston (1983), if post-stomachal transit is similar for particulate and solute markers, their respective retention in the second mixingcompartment $\mathrm{C} 2$ should be the same. Data from table VII show they were different when considering the model Gw1. Values were moderately correlated $\langle r=0.58$; slope 0.38 different from unity $(P<0.01))$. This was observed even though particle and solute markers had effectively the same $(P \geq 0.05)$ post-stomachal retention time (table VIII). This MRT was calculated directly by subtracting stomachs $M R T$ from whole tract MRT. Differences between means, although slight, were most

Table VI. Influence of sampling site on particulate and solute markers MRT in the rumen estimated from faecal and duodenal marker kinetics.

\begin{tabular}{|c|c|c|c|c|c|c|c|c|c|c|}
\hline \multirow{2}{*}{$\begin{array}{l}\text { Partial } \\
\text { MRT }^{3}\end{array}$} & \multirow{2}{*}{$\begin{array}{l}\text { Administration } \\
\text { /marker }^{4}\end{array}$} & \multirow{2}{*}{ Model $^{5}$} & \multicolumn{2}{|c|}{$\operatorname{Mean}(S D)^{1}$} & \multicolumn{6}{|c|}{ Regression parameters ${ }^{2}$} \\
\hline & & & Faeces $(F)$ & Duodenum (D) & $x$ & $Y$ & Slope & Intercept & Syx & $r$ \\
\hline \multirow[t]{2}{*}{$\mathrm{C} 1$} & $P D /$ Eu & Gw1 & $26.2(4.23)^{\mathrm{a}}$ & $22.5(5.45)^{\mathrm{b}}$ & $\mathrm{F}$ & $D$ & & & & 0.204 \\
\hline & $P I N b$ & Gw2 & $24.5(5.02)^{a}$ & $20.6(4.83)^{\mathrm{b}}$ & $\mathrm{F}$ & $\mathrm{D}$ & 0.597 & 6.0 & 3.9 & 0.622 \\
\hline \multirow[t]{2}{*}{$\mathrm{C} 1$} & PDPEG & Gw1 & $16.6(2.88)^{\mathrm{a}}$ & $8.9(3.24)^{b}$ & $\mathrm{~F}$ & $\mathrm{D}$ & & & & 0.416 \\
\hline & PI/Cr-EDTA & Gw2 & $22.8(4.85)^{\mathrm{a}}$ & $13.3(3.70)^{\mathrm{b}}$ & $\mathrm{F}$ & $\mathrm{D}$ & & & & 0.370 \\
\hline
\end{tabular}

\footnotetext{
${ }^{1}$ Means in the same line with different superscripts $(a, b)$ are different $\langle P<0.05) ;{ }^{2}$ Syx residual SD; $r$ correlation coefficien ; ${ }^{3,4,5}$ for details, see text.
} 
Table VII. Comparisons between partial MRT of particulate $(P)$ and solute (S) markers in mixing compartments ( $\mathrm{C} 1$ and $\mathrm{C} 2$ ) obtained by modelling faecal marker kinetics.

\begin{tabular}{|c|c|c|c|c|c|c|c|c|c|}
\hline \multirow{2}{*}{$\begin{array}{l}\text { Partial } \\
\text { MRT }^{2}\end{array}$} & \multirow{2}{*}{$\begin{array}{l}\text { Administration } \\
\text { /marker }^{3}\end{array}$} & \multirow[t]{2}{*}{ Model $^{4}$} & \multirow[t]{2}{*}{$\operatorname{Mean}(S D)^{5}$} & \multicolumn{6}{|c|}{ Regression parameters ${ }^{1}$} \\
\hline & & & & $x$ & $Y$ & Slope & Intercept & Syx & $r$ \\
\hline C1 & $\begin{array}{l}P D / \text { EU } \\
P D / \text { PEG }\end{array}$ & $\begin{array}{l}\text { Gw1 } \\
\text { Gw1 }\end{array}$ & $\begin{array}{ll}26.2 & (4.23)^{\mathrm{a}} \\
16.6 & (2.88)^{\mathrm{b}}\end{array}$ & $\mathbf{P}$ & $s$ & 0.32 & 8.2 & 2.6 & 0.474 \\
\hline $\mathrm{C} 2$ & $\begin{array}{l}P D / \text { Eu } \\
P D / \text { PEG }\end{array}$ & $\begin{array}{l}\text { Gw1 } \\
\text { Gw1 }\end{array}$ & $\begin{array}{r}14.7(2.77)^{\mathrm{a}} \\
8.72(1.83)^{\mathrm{b}}\end{array}$ & $P$ & $S$ & 0.37 & 3.1 & 1.58 & 0.580 \\
\hline
\end{tabular}

${ }^{1}$ Syx residual SD; $r$ correlation coefficient; ${ }^{2,3,4}$ for details, see text; ${ }^{5}$ within the same partial $M R T$, means with different superscripts $(\mathrm{a}, \mathrm{b})$ are different $(P<0.05)$.

Table VIII. MRT of particulate (P) and solute (S) markers in the post-stomachal section of the digestive tract of sheep obtained by numerical integration and modelling faecal marker kinetics.

\begin{tabular}{|c|c|c|c|c|c|c|c|c|}
\hline \multirow{2}{*}{$\begin{array}{l}\text { Administration } \\
\text { /marker }^{2}\end{array}$} & \multirow[t]{2}{*}{ Model $^{3}$} & \multirow[t]{2}{*}{ Mean $(S D)^{4}$} & \multicolumn{6}{|c|}{ Regression parameters ${ }^{1}$} \\
\hline & & & $x$ & $Y$ & Slope & Intercept & Syx & $r$ \\
\hline $\begin{array}{l}\text { PD/EU } \\
\text { PD/PEG }\end{array}$ & $\begin{array}{l}\text { Th } \\
\text { Th }\end{array}$ & $\begin{array}{l}27.7(6.38)^{a} \\
22.0(3.83)^{b}\end{array}$ & $\mathbf{P}$ & $S$ & $0.51^{* *}$ & $7.98^{* *}$ & 2.11 & 0.845 \\
\hline $\begin{array}{l}\text { PD/Eu } \\
\text { PD/PEG }\end{array}$ & $\begin{array}{l}\text { Gw1 } \\
\text { Gw1 }\end{array}$ & $\begin{array}{l}27.0(7.77) \\
27.2(4.40)\end{array}$ & $P$ & $\mathrm{~S}$ & $0.37^{* *}$ & $17.1^{* \star}$ & 3.41 & 0.660 \\
\hline $\begin{array}{l}\text { PI/Yb } \\
\text { PI/Cr-EDTA }\end{array}$ & $\begin{array}{l}\mathrm{Fa} 2 \\
\mathrm{Fa} 2\end{array}$ & $\begin{array}{l}22.1(6.89)^{a} \\
21.5(5.67)^{b}\end{array}$ & $P$ & $\mathrm{~S}$ & 0.77 & 5.67 & 5.51 & 0.632 \\
\hline $\begin{array}{l}\text { PI/Yb } \\
\text { PI/Cr-EDTA }\end{array}$ & $\begin{array}{l}\text { Gw2 } \\
\text { Gw2 }\end{array}$ & $\begin{array}{l}23.6(6.09)^{a} \\
25.7(6.33)^{b}\end{array}$ & $\mathbf{P}$ & $\mathrm{S}$ & 0.79 & 7.14 & 4.27 & 0.757 \\
\hline
\end{tabular}

1 Slope and intercept different from 1 and 0 respectively ( ${ }^{* *} P<0.01$ ); Syx residual SD; $c$ correlation coefficient; 2,3 for details, see text; ${ }^{4}$ within the same model, $r$ means with different superscripts $(a, b)$ are different $(P<0.05)$.

often significant $(P<0.05)$. Correlations between particle and solute markers MRT in post-stomachal sections of the gut were significant $(P<0.01)$ within a given model but relationships were often highly biased $(P<0.01)$.

\section{DISCUSSION}

The time spent by feeds and digesta in the tract of ruminants may affect both rumen degradation and intestinal digestion and absorption functions. This MRT is difficult 
to measure accurately, especially for particulate matter. This digesta phase is heterogeneous in physical features and chemical composition, and neither of the markers used in the present study can be considered to represent it. As a result, marker choice and labelling techniques are certainly more critical in estimating MRT and dynamics of solid digesta (Coleman et al, 1984; Ellis and Beever, 1984; Faichney, 1986; Faichney et al, 1989) than data analysis per se. There are, however, numerous techniques of marker administration and MRT (total or partial) calculation methods which may in turn affect the reliability of such results, as pointed out by Warner (1981). Besides methodological considerations, then appears the problem of sensitivity of transit measurement to dietary manipulations.

\section{Antibiotic supplementation and transit of particulate and solute digesta markers}

The influence of ionophore antibiotics on digesta transit in the gut and more precisely in the rumen still remains controversial, since significant effects on digesta flow could or could not be linked to changes in the retention of digesta (Spears, 1990). This would suggest the mode of antibiotic action on ruminal metabolism to be more complex than expected from known interrelationships between digesta turnover rate and microbial activity. Indeed, we found that microbial protein synthesis was greatly depressed by adding lasalocid or cationomycin to the basal diet but effects on the apparent digestion of nitrogen and plant cell walls in the rumen were not significant (Bogaërt et al, 1991; Gomez et al, 1991). Nevertheless, in our experimental conditions, neither marker administration techniques nor MRT calculation/partitioning methods were able to detect any significant change with antibiotic supplementation in particle and solute markers MRT (table II).

\section{Marker administration and MRT calculation methods}

As previously noted (Lallès et al, 1988, 1991), both algebraic methods compared (Faichney, 1975; Thielemans et al, 1978) similarly estimated the total MRT of particle and solute markers. The faecal excretion which is basically discrete may be assumed to be a continuous process, provided steady-state conditions are observed and sampling interval is not too large. However, these MRT estimates differ consistently from those obtained following the post-infusion technique in the case of particulate markers.

These expected differences are primarily the consequence of the preferential labelling of small particles including microbes, and to the fact that a significant amount of the marker remains in solution when lanthanides are infused in the rumen. Seventeen percent of the marker ( ${ }^{169} \mathrm{Yb}$ infused as chloride) was recovered in the supernatant after samples of rumen contents from sheep fed fresh forage or concentrate diets had been centrifuged at $40000 \mathrm{~g}$ (Al Abd, 1986). Also in that experiment, the radioactivity concentrated in the particulate fraction not retained on a $0.16 \mathrm{~mm}$ sieve and precipitated at $500 \mathrm{~g}$. That fraction is known to contain small feed particles and associated bacteria, free-floating bacteria, bacterial clumps and protozoa. It is noteworthy that radioactivity distribution among the different physical fractions of rumen contents paralleled that of microbial markers, DAPA (LegayCarmier and Bauchart, 1989) or ${ }^{15} \mathrm{~N}$ (Yang, 1991). When particles are labelled prior to introduction into the rumen using a 
competitive procedure (Ellis and 3eever, 1984) to bind the marker selectively on sites of strong affinity, its uneven distribution according to particle size is greatly reduced or even disappears (C Poncet, unpublished results).

The presence of lanthanides in solution in rumen liquid may be related to their affinity for soluble molecules like VFA, organic acids and various forms of nitrogen compounds (Teeter et al, 1984). Reasons for which lanthanides concentrate on small particle fraction in the rumen are not really understood, even if this has been reported frequently (Erdman and Smith, 1985; Siddons et al, 1985; Al Abd, 1986). It may be a passive surface phenomenon probably amplified by the fact that bacteria and perhaps protozoa are strongly labelled by lanthanides (Poncet, 1976; Combs et al, 1984) because of their size and/or ability to metabolize these markers (Johnson and Kyker, 1966). The role of microbes in marker migration generally evoked when discussing results obtained with rare earths (Poncet, 1976; Faichney and Griffiths, 1978; Hartnell and Satter, 1979; Crooker et al, 1982; Mader et al, 1984) is probably of prime importance. Migration may be preferentially directed towards small feed particles if they are more colonized by microbes than larger ones. Lanthanides infused as chloride or any other highly ionised form may precipitate as hydroxide at the rumen $\mathrm{pH}$ (Siddons et al, 1985). This would in turn increase the amount of particulate marker flowing in association with the liquid and small particle phase of digesta.

All these phenomena would tend to underestimate the actual MRT of particulate markers (Faichney, 1986). This was effectively observed in the present work when considering the low marker MRT values obtained after infusion arrest.
Secondly, the marker administration techniques compared do not exactly represent the same sum of basic events. Markers were dosed as a bolus in one case, whereas in the second case they were evenly distributed throughout the rumen at zero time. This difference in marker mixing could also explain part of the differences observed between pulse-dose and infusion-arrest techniques. This remark is supported by the results of Dehareng and Godeau (1989) who found no significant differences between these techniques in estimating ruminal solute marker turnover, and by the fact that such differences here are much lower for solute than for particulate markers.

Thirdly, different markers were used in each administration technique which may account for a presumably marginal part of the observed differences in markers MRT. Based on theoretical aspects, lanthanides $\mathrm{Eu}$ and $\mathrm{Yb}$ were assumed to exhibit similar affinities for plant cell walls, although some differences between them could be related to adsorption side-effects in the presence of metabolite molecules in the rumen (A)len and Van Soest, 1984; Ellis and Beever, 1984; Teeter et al, 1984). Nevertheless, direct comparisons suggest behaviour in ruminant digesta to be similar among rareearths, but to differ from that of Ruphenanthroline and of $\mathrm{Cr}$-mordanted fibre (Ellis et al, 1980; Dixon et al, 1983; Goetsch and Galyean, 1983; Weiss and Martz, 1983; Al Abd, 1986; Gonzalez et al, 1987; Satter et al, 1987; Pond et al, 1989).

Regarding solute markers $M R T$ in the entire tract, results in table IV showed that both markers led to similar MRT estimates regardless of marker administration technique. PEG and Cr-EDTA proved to behave similarly when used in digesta flow experiments (Downes and McDonald, 1964; Binnerts et al, 1968; Peyraud, 1983; 
Al Abd, 1986; Poncet and Al Abd, 1987). When used as transit markers, PEG and metal-EDTA ( $\mathrm{Cr}, \mathrm{Co})$ generated similar estimates of liquid MRT (Teeter and Owens, 1983; Doreau et al, 1987), although large but not systematic behavioural differences have been reported (Poncet and Al Abd, 1984). It may therefore be reasonably deduced from our observations that mixing of solute markers in the rumen of our sheep was practically instantaneous.

At the duodenum level, a fairly similar pattern has been observed (table IV). This would indicate that MRT differences between marker administration techniques arise from phenomena essentially located in the stomachs (rumen). However, MRT differences in the post-stomachal section of the gut are apparent (table VIII) and more difficult to interpret.

\section{Modelling and MRT partitioning among compartments of models}

As already observed in sheep (Faichney and Boston, 1983) and ruminant calves (Lallès et al, 1991), modelling faecal marker kinetics generally overestimates MRT calculated by numerical integration and may consequently limit the use of such models.

Two mathematical expressions of the functioning of a similar 2-mixingcompartment-one-delay deterministic system in which markers had been given using either a pulse dose or a post-infusion technique were compared. Beyond strict comparisons and differences, a sigmoid curve following marker infusion arrest and a "bell-shape" curve after single-dose administration of marker could be fitted satisfactorily using respective equations, as judged by the proportion of total variance accounted for by models. However, MRT partitioning among 3 compartments appeared to raise specific problems with the S-shape kinetics. Indeed, partial MRT ascribed to the second mixing compartment $\mathrm{C} 2$ obviously was greatly underestimated (Grovum and Williams, 1973; Dixon et al, 1982). This may be related to variations with time in the initial marker concentration at the plateau, the vicinity and the quite undifferentiable shape of the curve portion underlying $\mathrm{C} 2$ MRT estimation. Undoubtedly, if MRT in C2 reflects retention in the caecum-proximal colon compartment (Grovum and Williams, 1973), the Gw2 model used in the present work was not adapted to estimate C2 MRT, and probably other partial MRTs. A simplified form may be derived to estimate only 2 transit components $(T T+C 2)$ and $C 1$.

\section{Rumen MRT estimated from faecal kinetic data}

As already observed in our laboratory (Poncet and Al Abd, 1984; Lallès and Poncet, 1990b) and in agreement with other results (Faichney and Boston, 1983; Robinson and Sniffen, 1983; Goetsch and Owens, 1985; Cochran et al, 1986; Beauche$\min$ and Buchanan-Smith, 1989; Cruickshank et al, 1989), the present study confirms that it could be hazardous to estimate ruminal $M R T$ from faecal data. However, high correlations have been found between rumen or duodenal and faecal slopes of decreasing parts of marker concentration kinetics (Elimam and Ørskov, 1984; Ellis et al, 1984) suggesting such an approach may be satisfactory in dietary situations in which very long relative retention of digesta in the rumen occurs. 


\section{CONCLUSION}

In conclusion, the addition of cationomycin and lasalocid to a roughage-based diet had no significant effect on the retention of solute and particulate markers in sheep regardless of sampling site, marker administration technique or MRT calculation used. Pulse-dose and post-infusion techniques led to differences which may be explained by the difference between ways of labelling rumen contents (infusion of a solution of marker vs pulse dose of pre-labelled feed particles) and the subsequent specific behaviour of markers in the digestive tract following their administration. Partitioning MRT among 3 partial MRTs using a deterministic model seemed to be difficult in the case of the post-infusion technique. More direct investigations are required to validate the estimation of markers MRT using models.

\section{REFERENCES}

Adams DC, Galyean ML, Kiesling HE, Wallace JD, Finkner MD (1981) Influence of viable yeast culture, sodium bicarbonate and monensin on liquid dilution rate, rumen fermentation and feedlot performance of growing steers and digestibility in lambs. J Anim Sci 53, 780-789

Al Abd A (1986) Comparaison des méthodes de mesure du flux des contenus digestifs chez le ruminant; application à l'étude de la digestion de trois types de ration. Thèse Doctorat Université de Clermont II

Allen JD, Harrison DG (1979) The effect of dietary addition of monensin upon digestion in the stomachs of sheep. Proc Nutr Soc 3, 32A

Allen MS, Van Soest PJ (1984) Periodicity and variation in the binding of rare earth ions to plant cell wall particles. In: Techniques in Particle Size Analysis of Feed and Digesta in Ruminants (Kennedy PM, ed) Can Soc Anim Sci, Edmonton, 180-183
Arndt DL, Richardson CR (1985) Effect of sodium hydroxide, monensin and $\mathrm{pH}$ on rumen turnover rate of cotton plant by-product by lambs. Nutr Rep Int 31, 687-694

Beauchemin KA, Buchanan-Smith JG (1989) Evaluation of markers, sampling sites and models for estimating rates of passage of silage or hay in dairy cows. Anim Feed Sci Technol 27, 59-75

Binnerts WT, Van't Klooster AT, Frens AM (1968) Soluble chromium indicator measured by atomic absorption in digestion experiments. Vet Rec 82, 470

Bogaërt C, Gomez L, Jouany JP (1991) Effects of lasalocid and cationomycin on the digestion of plant cell walls in sheep. Can J Anim Sci 71, 379-388

Cochran RC, Adams DC, Galyean ML, Wallace JD (1986) Estimating particle turnover in the rumen of meal fed beef steers: procedural evaluations. J Anim Sci 63, 1469-1475

Coleman SW, Evans BC, Horn GW (1984) Some factors influencing estimates of digest turnover rate using markers. J Anim Sci 58, 979-986

Combs DK, Shaver RD, Singh N, Satter LD (1984) Effects of application procedure, $\mathrm{pH}$ and microbial growth on retention of ytterbium or cerium by brome hay. Can J Anim Sci 64 (suppl) 66-67

Crooker 8A, Clark JH, Shanks R (1982) Rareearth elements as markers for rate of passage measurements of individual feedstuffs through the digestive tract of ruminants. J Nutr 112, 1353-1361

Cruickshank GJ, Poppi DP, Sykes AR (1989) Theoretical considerations in the estimation of rumen fractional outflow rate from various sampling sites in the digestive tract. Br J Nutr 62, 229-239

Darden DE, Merchen NR, Berger LL, Fahey GC, Spears JW (1985) Effects of avoparcin, lasalocid and monensin on sites of nutrient digestion in beef steers. Nutr Rep Int 31, 979-989

Dehareng D, Godeau JM (1989) Polyethylene glycol dilution curves: a comparison of apparent ruminal liquid volumes and dilution rates estimates from either ruminal or duodenal fluid samples of Friesian cows. J Anim Physiol Anim Nutr 62, 268-276 
Delaney DS, Ellis WC (1983) Intraruminal responses to monensin in grazing cattle. J Anim Sci 57 (suppl 1), 428

Dixon RM, Kennelly JJ, Milligan LP (1983) Kinetics of [ $\left.{ }^{103} \mathrm{Ru}\right]$-phenanthroline and dysprosium particulate markers in the rumen of steers. Br J Nutr 49, 463-473

Dixon RM, Nolan JV, Milligan LP (1982) Studies of the large intestine of sheep. 2. Kinetics of liquid and solid phase markers in the caecum and proximal colon. Br J Nutr 47, 301309

Doreau M, Le Guen MP, Poncet C (1987) Vitesse de renouvellement du liquide du rumen mesurée par le polyéthylène glycol et le Co-EDTA à trois niveaux du tube digestif. Reprod Nutr Dev 27, 227-228

Downes AM, McDonald IW (1964) The chromium-51 complex of ethylene-diamine tetraacetic acid as soluble rumen marker. $\mathrm{Br} J$ Nutr 18, 153-162

Elimam ME, Ørskov ER (1984) Estimation of rate of outflow of protein supplement from the rumen by determining the rate of excretion of chromium-treated protein supplements in faeces. Anim Prod 39, 77-80

Ellis WC, Beever DE (1984) Methods for binding rare earths to specific feed particles. In: Techniques in Particle Size Analysis of Feed and Digesta in Ruminants (Kennedy PM, ed) Can Soc Anim Sci Edmonton, 154-165

Ellis WC, Lascano C, Teeter R, Owens FN (1980) Solute and particulate flow markers. In: Protein Requirement for Cattle. Symposium (Owens FN, ed) Okl State Univ, Misc Publ, MP 409, 37-55

Ellis WC, Matis JH, Pond KR, Lascano CE, Telford JP (1984) Dietary influences on flow rate and digestive capacity. In: Herbivore Nutrition in Subtropics and Tropics (Gilchrist FMC, Mackie RI, eds) The Science Press, Johannesburg, 269-293

Erdman RA, Smith LW (1985) Ytterbium binding among particle size fractions of forage cell walis. J Anim Sci 68, 3071-3075

Evans E (1981a) An evaluation of the relationships between dietary parameters and rumen liquid turnover rate. Can J Anim Sci 61, 91-96

Evans E (1981b) An evaluation of the retationships between dietary parameters and ru- men solid turnover rate. Can J Anim Sci 61, 97-103

Faichney GJ (1975) The use of markers to partition the digestion within the gastrointestinal tract of ruminants. In: Digestion and Metabolism in the Ruminant (Warner $\mathrm{ACl}, \mathrm{McDo}$ nald IW, eds) The Univ N Engl Publ Unit, Sidney, 277-291

Faichney GJ (1986) The kinetics of particulate matter in the rumen. In: Control of Digestion and Metabolism in Ruminants (Milligan LP, Grovum WL, Dobson A, eds) Reston, VA, 173-195

Faichney GJ, Boston RC (1983) Interpretation of the faecal excretion patterns of solute and particle markers introduced into the rumen of sheep. J Agric Sci (Camb) 101, 575-581

Faichney GJ, Griffiths GA (1978) Behaviour of solute and particle markers in the stomachs of sheep given a concentrate diet. $B r J$ Nutr 40, 71-82

Faichney GJ, Poncet C, Boston RC (1989) Passage of internal and external markers of particulate matter through the rumen of sheep. Reprod Nutr Dev 29, 325-337

Faulkner DB, Klopfenstein TJ, Trotter TN, Britton RA (1985) Monensin effects on digestibility, ruminal protein escape and microbial protein synthesis on high-fiber diets. J Anim Sci $61,654-660$

Gill JL (1978) Changeover designs: sequences of treatments. Estimation of residual effects of treatments. In: Design and Analysis of Experiments in the Animal Medical Sciences, 179-187

Goetsch AL, Galyean ML (1983) Rutheniumphenantroline, dysprosium and ytterbium as particulate markers in beef steers fed an allalfalfa hay diet. Nutr Rep Int 27, 171-178

Goetsch AL, Owens FN (1985) Effets of sampling site on passage rate estimates in heifers fed alfalfa hay or a hay concentrate diet. J Dairy Sci68, 914-922

Gomez L, Bogaërt C, Jouany JP, Lassalas B (1991) The influence of lasalocid and cationomycin on nitrogen digestion in sheep; comparison of methods for estimating microbial nitrogen. Can J Anim Sci 71, 389-399

Gonzalez J, Poncet C, Michalet-Doreau B (1987) Comparaison de deux types de marqueurs, terres rares et chrome mordancé, 
pour la mesure du temps de séjour des aliments dans les estomacs du ruminants. $R e$ prod Nutr Dev 27, 221-222

Grovum WL, Williams VJ (1973) Rate of passage of digesta in sheep. 4. Passage of marker through the alimentary tract and the biological significance of rate-constants derived from the changes in concentration of marker in faeces. Br J Nutr 30, 313-329

Hartnell GF, Satter LD (1979) Extent of particulate marker (samarium, lanthanum and cerium) movement from one digesta particle to another. J Anim Sci 48, 375-380

Hydén S (1955) A turbidimetric method for the determination of higher polyethylene glycols in biological materials. Kungl Lantbr Ann 22, 139-145

Johnson GT, Kyker GC (1966) Mechanism of cerium uptake by Saccharomyces cerevisiae. Mycologia 58, 91-99

Lallès JP, Poncet C (1990a) Changes in ruminal and intestinal digestion during and after weaning in dairy calves fed concentrate diets containing pea or soya bean meal. I. Digestion of organic matter and nitrogen. Livest Prod Sci 24, 129-142

Lallès JP, Poncet C (1990b) Rate of passage of digesta during and after weaning in calves fed concentrate diets containing pea or soya bean meal. Livest Prod Sci 24, 333-345

Lallès JP, Delval E, Poncet C (1988) Mesure du transit digestif chez le veau ruminant : comparaison et validation des modèles d'ajustement des cinétiques de passage. $R e$ prod Nutr Dev 28 (suppl 1), 151-152

Lallès JP, Delval E, Poncet C (1991) Mean retention time of dietary residues within the gastrointestinal tract of the young ruminant: a comparison of non-compartmental (algebraic) and compartmental (modelling) estimation methods. Anim Feed Sci Technol 35, 139159

Legay-Carmier F, Bauchart D (1989) Distribution of bacteria in the rumen contents of dairy cows given a diet supplemented with soyabean oil. Br J Nutr 61, 725-740

Lemenager RP, Owens FN, Shockey BJ, Lusby KS, Totusek R (1978) Monensin effects on rumen turnover rate, twenty-four hour VFA pattern, nitrogen components and cellulose disappearance. J Anim Sci 47, 255-261
Leng RA, Nolan JV, Cumming G, Edwards SR, Graham CA (1984) The effects of monensin on the pool size and turnover rate of protozoa in the rumen of sheep. $J$ Agric $\mathrm{Sci}$ (Camb) 102, 609-613

Mader TI, Teeter RG, Horn GW (1984) Comparison of forage labeling techniques for conducting passage rate studies. J Anim Sci 58 , 208-212

Malawer ST, Powell W (1967) An improved turbidimetric analysis of polyethylene glycol utilizing an emulsifier. Gastroenterology 53, 250-256

Peyraud JL (1983) Rôles respectifs des enzymes de l'hôte et de la flore intestinale sur la digestion de l'amidon et de ses dérivés (produits amylacés) chez le jeune agneau préruminant. Thèse de Docteur-Ingénieur Université de Rennes I, 173 pp

Poncet C (1976) Utilisation du Cérium 141 comme marqueur de la phase solide des contenus digestifs chez le ruminant. Ann Biol Anim Biochim Biophys 16, 731-739

Poncet C, Al Abd A (1984) Particulate and fluid passage studies in sheep fed a hay-based diet. Can J Anim Sci64 (suppl), 77-79

Poncet C, Al Abd A (1987) Evaluation de la technique du double marquage appliquée à la mesure du flux duodénal chez le mouton. Reprod Nutr Dev 27, 225-226

Pond KR, Ellis WC, Matis JH, Deswysen AG (1989) Passage of chromium-mordanted and rare-earth labeled fiber: time of dosing kinetics. J Anim Sci 67, 1020-1028

Quiroz RA, Pond KR, Tolley GA, Johnson WL (1988) Selection among non-linear models for rate of passage studies in ruminants. J Anim Sci 66, 2977-2986

Ricke SC, Berger LL, Van der Aar PJ, Fahey GC (1984) Effects of lasalocid and monensin on nutrient digestion, metabolism and rumen characteristics of sheep. J Anim Sci 58, 194202

Robinson PH, Sniffen CJ (1983) Comparison of rumen, duodenal and faecal sampling sites to estimate ruminal turnover rates of markers in cows. J Dairy Sci 66, 187 (abstr)

Satter LD, Lopez-Guisa JM, Combs DK (1987) Utilization of maize crop residues by growing dairy heifers and use of rare earth elements as digesta markers in the gut. In: Isotope- 
Aided Studies on Non-Protein Nitrogen and Agro-Industrial By-Products Utilization by Ruminants. Int Atom Energy Agency, Vienna, 89-101

Siddons RC, Paradine J, Beever DE, Cornell PR (1985) Ytterbium acetate as a particulate-phase digesta-flow marker. Br J Nutr 54 , 509-519

Snedecor GW, Cochran WG (1971) Méthodes Statistiques (Boelle $\mathrm{H}$, Camhaji E, eds) Assoc Coor Tech Agric, Paris, 6th edn

Spears JW (1990) lonophores and nutrient digestion and absorption in ruminants. $J$ Nutr $120,632-638$

Teeter RG, Owens FN (1983) Characteristics of water soluble markers for measuring rumen liquid volume and dilution rate. $J$ Anim Sci 56, 717-728

Teeter RG, Owens Fn, Mader TL (1984) Yttterbium chloride as a marker for particulate matter in the rumen. J Anim Sci 58, 465-473

Thielemans MF, François E, Bodart C, Thewis A (1978) Mesure du transit gastrointestinal chez le porc à l'aide de radiolanthanides. Comparaison avec le mouton. Ann Biol Anim Bioch Biophys 18, 237-247

Van Haecke $H$, van Nevel CJ, Dendooven R, Demeyer DI (1985) Effect of monensin on fermentation pattern and soyabean protein degradation in the rumen of sheep. Arch Tierernähr (Berlin) 53, 279-286
Van Nevel CJ, Demeyer DI (1979) Effect of monensin on some rumen fermentation parameters. Ann Rech Vet 10, 338-340

Ward MG, Adams DC, Wallace JD, Galyean ML, Knapp BW (1990a) Supplementation and monensin effects on digesta kinetics. I. Cattle grazing summer range. J Range Manage 43, 378-382

Ward MG, Adams DC, Wallace JD, Galyean ML, Volesky JD (1990b) Supplementation and monensin effects on digesta kinetics. II. Cattle grazing winter range. I Range Manage 43, 383-386

Warner ACl (1981) Rate of passage of digesta through the gut of mammals and birds. Nutr Abstr Rev Ser B 51, 789-820

Weiss $M$ (1981) Residual fiber passage rate studies in ruminants using free and fiberattached metal dietary marker. Nutr Res 3 , 583-593

Weiss MF, Martz FA (1983) Residual fiber passage rate studies in ruminants using free and fiber-attached metal dietary marker. Nutr Res 3, 583-593

Yang WZ (1991) Étude cinétique de la colonization microbienne des aliments dans le rumen du mouton. Conséquences sur la compartimentation de la biomasse et sur sa dynamique de sortie du rumen dans le cas de différents types de rations. Thèse Doctorat Université de Clermont II 